\title{
Mu’tazili Rationalism
}

\author{
Asst. Prof. Dr. Mustafa Bilgin \\ Bursa Uludağ University \\ Faculty of Theology \\ Basic Islamic Sciences, Department of Exegesis (Tafsir) \\ Turkey
}

\begin{abstract}
The epistemological dispute, which emerged about religious problematics in earlier periods of Islamic thought, led to a search of method regarding how to attain accurate knowledge. Mu'tazila was the first school to study in a methodological manner and to bring forward through a rational perspective how religious facts and divine truths can be comprehended in the best and most accurate way. According to Mu'tazila, intellect/reason [aql], which is the source of any knowledge, is also the source of religious knowledge and a measure for evaluation of religious truths. Hereby study puts forth such rationalist methodological approach of Mu'tazila to Islamic thought within the scope of problems of "evidence/proof" [dalil], "intuitive knowledge of Allah" [ma'rifatullah] and "prettiness-ugliness" [husn-qubh].
\end{abstract}

Keywords: Mu'tazila, Intellect/Reason (Aql), Theory/Thinking (Nazar), Knowledge, Evidence, Intuitive Knowledge of Allah (Ma'rifatullah), Prettiness and Ugliness (Husn and Qubh)

\section{Introduction}

Religion, one of the common human values, is often defined as a "divine law that leads the rational man to righteousness (salah) in the world and salvation (falah) in afterlife through his respective free choices" (al-Bayazi, 1949: p.68-69; al-Bustani, no date; VIII, 236). The religion is divided in two sections as theoretical and practical, more precisely, ma'rifa and ta' at (i'tiqad and amal, usul and furu') (al-Shahrastani, 1975: I, 41), and it is learned through two means, namely, aql and sam'/naql (al-Maturidi, 1979: p. 4). Both these means play an important part within two aspects of religion. Nevertheless, such sharing of areas occasionally led to generation of different knowledge on the same issue - due to difference of means - and ensuing epistemological dispute brought along the question of "how to comprehend religious facts and divine truths in the best and most correct manner."

Mu'tazila was the first Islamic school to deal with the issue and to deal with it through an approach in favor of intellect. According to Mu'tazila, intellect, which is the source of any knowledge (al-Shahrastani, 1975: I, 42), is also the source of religious knowledge and the measure to weigh religious truths. This is the first principle contributed by Mu'tazila to Islamic thought (Goldziher, 1955: p. 158-159). Once certain problems reflecting rationalism, the methodology of Mu'tazila, are clarified, we can see Mu'tazila developed the five-principle thought systems of "tawhid," "adl", "wa'd and wa'id", "manzila bayn al-manzilatayn" and "amr-i bi'l-ma'ruf wa'n-nahy-i ani'l-munqar" on the basis of essential approach adopted about the foregoing issues.

\section{Evidences}

Evidence is the instrument that enables being informed about a matter. For a religious research, the first thing to do is to identify means of knowledge and their evidential value. The relevant view of Mu'tazila is closely related with definition of "dalil" concept. Certain definitions of evidence are given below:

"Evidence is what takes one to the knowledge of matters that are beyond senses and that cannot be necessarily known" (al-Baqillani, 1957: p. 13).

"Evidence is what takes one to knowledge that is not necessarily established in traditional knowledge (not public), by means of authentic thinking. It is divided as rational and traditional" (al-Juwayni, 1985: 29).

"Evidence is what takes its thinker to knowledge of other thing [ghayr] if used appropriately" (al-Qadi, 1965: 87).

According to foregoing definitions, evidence is the means that "makes one informed about a previously unknown matter, on the condition of authentic thinking and appropriate use." The rational deed here describes methodic thinking expressed by the term "nazar" in Kalam tradition. Accordingly, "nazar" is defined as "intellectual effort to attain the unknown through appropriate processing of the known" (al-Juwayni, 1985: p. 25; al-Qadi, 1965: 45; al-Baqillani, 1957: 8-9; al-Tahanawi, 1984: II, 1388). 
Pursuant to brief explanations above, "sound thinking" is a prerequisite for "sound knowledge". According to Mu'tazila, the religious evidences (adilla al-shar'iyya) with abovementioned characteristics are Intellect, Book, Sunnah and Consensus, respectively (al-Qadi, 1965: p. 88). For example, in his exegesis of al-Baqarah 2/25, al-Zamakhshari (d. 538/1143) defines the word "الصالحات" (es-sâlihât) as "all deeds understood through proofs of Intellect, Book and Sunnah" (al-Zamakhshari, no date: I, 255) and mentions Intellect in the first place. Likewise, in his exegesis of Yusuf 12/111, he describes Quran as "the law to which Sunnah, Consensus and Deductive Analogy refers, after Intellectual proofs" (al-Zamakhshari, no date: II, 348), mentioning Intellect once again before the Book.

Mu'tazila attaches significant importance to intellect/reason in the realm of religion, as is reflected in their mentioning of Aql at the top of religious proofs. Al-Qadi Abduljabbar (d. 415/1024) explains their approach as follows: "Some are astonished in face of such formula and think that Intellect should come later in this composition since evidences consist of the Book, Sunnah and Consensus. This, however, is not true; indeed, Allah only addresses to the reasonable man, since the evidential quality of the Book, Sunnah and Consensus is known through reason/intellect. We may suppose 'The Book is the essence' for it not only includes evidence about judgments but also intellectual admonitions; nevertheless, Intellect comes first in terms of evidence, for intellect makes distinction between judgments for deeds and judgments for doers. If it hadn't been for intellect, we could have never known who would be questioned, praised or criticized for the deeds they abandon or fulfill. This is why a person without intellect is not responsible for accountability. We understand the Book is a proof only when we recognize a single God in all divineness and know Him as the All-Wise through intellect; we learn the words of Prophet are evidence only when we know Allah as the One Who sends Prophet and Who distinguishes him from liars via miraculous proofs" (al-Qadi, 1974: p. 139).

As the foregoing explanations of al-Qadi Abduljabbar reveal, Mu'tazila considers Intellect as the first and essential evidence in terms of religion and sees others as secondary; according to Mu'tazila, the evidential quality of the Book and Sunnah depend on the knowledge that they are Book of Allah and Sunnah of the Prophet. This fact primarily necessitates recognition of divineness and knowledge about Allah (ma'rifatullah). Intellect is the fundamental evidence about divinity. It is impossible to know the Book and Sunnah as evidence unless it is proven through intellect that Allah is "the being Who does not lie and Who does not carry out unwise deeds". The accuracy of reports in comprehensible through determination that their Reporter "does not lie and does not act unwisely," and not through their modalities. Such determination, in turn, requires another evidence, which is Intellect. Therefore, first, one has to recognize Allah through Intellect. This is why Intellect precedes others as evidence (al-Qadi, 1969: I, 1-5, 22-23; al-Qadi, 1965: 88-89).

\section{Ma'rifatullah}

According to Mu'tazila, the primary duty of man is to get informed about Allah by means of rational research (nazar). The subject is responsible for such research and knowing Allah thorough intellect even before impositions of Islamic law (al-Qadi, 1965: p. 39, 45, 65; al-Shahrastani, 1964: I, 42, 45). For example, in the beginning of his Sharh al-Usul al-Hamsa, al-Qadi Abduljabbar says: "If one comes to ask you what is the first thing Allah renders an obligation for you, you should reply: 'It is the thinking to take me to knowledge about Allah; indeed, Allah cannot be known through material knowledge or observation, namely, senses; therefore, we have to know Him by means of contemplation and thinking"' (al-Qadi, 1965: 39). The author then comprehensively explains that "thinking towards intuitive knowledge of Allah is the first duty of subject" (al-Qadi, 1965: 39-87).

According to Mu'tazila, ma'rifatullah, which is an obligation for subject, is based on the obligation of being grateful to intellect, power and other blessings granted for man. Such obligation is not judiciary but intellectual (al-Qadi, no date: 390, 467, 477; al-Razi, no date: XX, 180). Indeed, Allah has made thought on His blessings obligatory for man can deduct His existence and the gratefulness and worship worthy of Him can be known (al-Qadi, no date: 199-200, 385). Indeed, Allah bears the responsibility of guiding man to religion and right path, and of abolishing bad habits and excuses (al-Qadi, no date: 218, 465; al-Zamakhshari, no date: II, 403; al-Razi, no date: XIX, 231-232). This guidance to right path is the grant of possibility of attaining ma'rifatullah and demonstration of relevant evidence. Intellect and force granted to man constitutes this possibility; while occurrences in universe constitute these proofs (al-Zamakhshari, no date: I, 487; IV, 261). Man is liable to know Allah (ma'rifatullah) through these possibilities granted to him. This can happen by means of thought and deduction, in other words, contemplation on evidences and blessings in the universe (al-Qadi, no date: 17, 69; al-Razi, no date: VI, 174; XXIV, 245). The similar character of certain Quran verses is based on the same objective of making the addressee contemplate on proofs that takes him to knowledge of Allah (alQadi, no date: p. 58-59).

Since it is reasonably necessary to be grateful to giver of blessings, Mu'tazila agrees that man is responsible for knowing Allah even before sharia; accordingly, a person who does not fulfill this responsibility will deserve eternal punishment. 
Indeed, for Mu'tazila, human capacities of intellect, force, thought and deduction constitute the prerequisites for such proposal, together with proofs and blessings in universe (al-Ash'ari, 1980: I, 226-227; Ibn Hazm, 1975: IV, 2; alShahrastani, 1975: I, 52, 58, 65, 70, 71).

Evidently, the Mu'tazili theory of attaining knowledge of Allah through contemplation on proofs within universe (thought and deduction) puts the concept of prophethood in need of explanation. According to Mu'tazila, prophethood is not a denotation [hujjat] but benediction in terms of religious responsibility. More precisely, "Sending of prophets and revelation of books are not necessarily a prerequisite for faith in Allah and His unity. Even if Allah does not send prophet or reveal a book, the faith is obligatory by means of intellect, evidence, thought and deduction granted for man" (al-Zamakhshari, no date: I, 275). Indeed, Abraham came to know Allah by means of thinking and deduction; his tribe worshipped in idols, moon, sun and stars, but he showed them His eventual works within them so as to teach his people the "authentic thinking" that would enable them to attain the Being Who created and led all such existence (alZamakhshari, no date:II, 118). Likewise, prophets are persons who not only declare religious calls and teach religious laws, but also wake people from negligence and encourage them to think and deduct. Assignment of Prophets is not for obliging the call, but for warning negligent persons and preventing them from saying "We couldn't know. If only Allah sent us a prophet to encourage us to contemplate intelligible evidences!" (al-Zamakhshari, no date: II, 441-442), and removing any possible excuses (al-Zamakhshari, no date: I, 583). Therefore, prophethood is not an evidence but a divine grace and blessing. Indeed, evidence of unity of Allah - which is reason - is common between prophets and others (al-Qadi, no date: 134). Prophets are also prohibited from worshipping idols by means of intelligible proofs even before their prophethood (al-Qadi, no date: 134; al-Zamakhshari, no date: III, 435-436).

In brief, Mu'tazila defends that the subject has to know Allah through rational research called thought and deduction even before imposition of Islamic law, and that abandonment of such contemplation will require eternal punishment. Mu'tazila is accused by opponents of "proving an intelligible Islamic jurisdiction" since it ascribes such great authority and responsibility to Intellect (al-Shahrastani, 1975: I, 81). For sure, such accusation is not only because of the assertion that it is necessary to know Allah by means of reason even before imposition of sharia. Instead, the accusation is based on Mu'tazili requirement of issues other than ma'rifatullah for man. Indeed, apart from this intellectual/faithrelated responsibility in terms of "ma'rifa", Mu'tazili ascribes to another intelligible principle and consider some practical issues, which are within "ta' at" aspect of religion, as necessary. This other intelligible principle is "Prettiness and Ugliness" (Good and Evil), also known as "Problematic of Husn and Qubh".

\section{Husn and Qubh}

According to Mu'tazila, the primary duty of man is to know Allah by means of thinking (Ma'rifatullah). All other words and deeds (amal, ta'at, sharia), for which man is responsible, can become good only in the wake of ma'rifatullah (al-Qadi, 1965: 69-70, 75-76).

Having accepted the theoretical research towards ma'rifatullah as the primary obligation, Mu'tazila concentrates on human behaviors in search for an intellectual principle to discipline human deeds. The relevant perspective is based on classification of deeds as "pretty/good" (hasan) and "ugly/evil" (qabih). For Mu'tazilites, prettiness and ugliness are essential qualities of deeds (al-Shahrastani, 1964: 376; 1975: I, 42). Intellect can know whether behaviors are good or evil by means of these qualities. Pursuant to such knowledge, it is reasonably obligatory for intellect to fulfill what is good and to avoid what is evil. Then again, it is obligatory for Allah to provide thawab and punishment for good and evil deeds of subjects, respectively (al-Qadi, 1965: 41-43, 64-71; al-Baghdadi, 1927: 26; al-Shahrastani, 1964: 371; 1975: I, 45).

Hereby Mu'tazili approach can be explained as follows: Deeds can be divided in three in terms of reason, namely, obligation, objection and permissible. Obligation (wajib) is the deed the avoidance of which requires punishment. Objection (haram) is the behavior the commitment of which requires punishment. Permissible is the deed of which avoidance or commitment does not require any punishment (al-Baghdadi, 1927: 199, 208).

There is no change in terms of Sharia as to deeds that are demonstrated to be obligatory by intellect. This is the case for obtaining knowledge about Allah or paying gratitude for His blessings. The same applies for deeds which are considered objectionable by intellect. This is the case for haram quality of denial of belief and ingratitude to blessings (al-Baghdadi, 1927: 25).

According to Mu'tazila, intellect/reason is the way of learning obligatory and objectionable deeds, since deeds are good or evil depending on their essential qualities. Thus, intellect can comprehend them through such qualities and distinguish pretty from ugly and good from evil. Therefore, intellect may conclude on prettiness or ugliness of something by looking at its own quality and decide whether such thing is obligatory or objectionable (fard or haram) for man. In fact, this is why deeds are declared fard or haram by Sharia. 
Therefore, it is obligatory for intellect to learn whether a deed is good or evil before sharia and to process or abandon them pursuant to such knowledge. Whoever fulfils such intellectual duties prior to sharia deserves praise and thawab, whereas whoever abandons them deserves condemnation and punishment (al-Baghdadi, 1927: 25-27; al-Juwayni, 1985: 229; al-Ghazali, 1904: I, 56-57, 63-65; al-Shahrastani, 1964: 371).

Arguing that "what is pretty for intellect is pretty for sharia; what is ugly for intellect is ugly for sharia", Mu'tazila ascribes jurisprudent thawab and punishment on intellectual obedience and nonobedience and reaches to an intellectual conclusion also for afterlife. Mu'tazila classifies deeds as intellectually pretty and ugly, and divides them into pursuant to another intellect-based classification:

1) The prettiness or ugliness of which is known through material and apparent reason (explicitly) without need for further intellectual effort: Man knows righteousness and justice is pretty, and lie and cruelty is ugly, even without any intellectual effort about them.

2) The prettiness or ugliness of which is known through theoretical and deductive reason (rational research): Theoretical reason is required to know the prettiness of telling the truth even if it will harm one, and of not lying even if it will bring him advantage (al-Ghazali, 1904: I, 56).

\section{Conclusion}

Epistemological dispute about religious problems during earlier periods of Islamic thought brought along the requirement for search of a solid method and ground to attain correct religious knowledge. Mu'tazila became the first school to notice such need and to try to establish methodology of religion on the axis of intellect/reason. Mu'tazila considers intellect as the source of all knowledge, including religious, and tries to systematize theoretical and practical issues of Islam with focus on intellect and wisdom. Indeed, Mu'tazila lists religious proofs as Intellect, Book, Sunnah and Consensus, respectively, placing Intellect (Aql) to the top. Indeed, the evidential quality of Book, Sunnah and Consensus can be known through reason; besides, man can know a single Divinity only by means of reason, thereupon the Book of such known Divinity is accepted as evidence. Mu'tazila accepts thinking towards ma'rifatullah as the primary fard, before seeking the intellectual principle to discipline human deeds and classifying them as "good" and "evil". For Mu'tazila, good (husn) and evil (qubh) are essential qualities of deeds; intellect can know whether human deeds are good or evil through these qualities; accordingly, it is reasonably obligatory that man, who is informed thanks to blessing of intellect, fulfils the good and avoids the evil, and that Allah responds to human good with thawab and human evil with punishment.

\section{Bibliography}

al-Qur'an al-Karim

al-Baghdadi, Abu Mansur Abdulkahir b. Tahir al-Tamimi. (1927). Usul al-Din. İstanbul.

al-Baqillani, al-Qadi Abu Bakr Muhammad at-Tayyib. (1957). Kitab al-Tamhid (Publ.: Richard J. McCarthy, S. J.). Beirut: al-Maqtabat alSharqiyya.

al-Bayazi, Kamaluddin Ahmad b. al-Hasan. (1949). Isharat al-Maram min Ibarat al-Imam (Edit: Yusuf Abdurrezzak). Egypt.

Bilgin, M. (1991). Tefsirde Mu’tezile Ekolü. Unpublished PhD Dissertation. Uludağ University Institute of Social Sciences. Bursa. al-Bustani, Butras. (no date). Kitab al-Da'irat al-Ma'arif(Volume I-XI). Tehran.

al-Juwayni, Abu'l-Ma'ali Abdulmalik. (1985). Kitab al-Irshad (Edit: Es'ad Temim). Beirut.

al-Ash'ari, Abu'l-Hasan Ali b. İsmail. (1980). Maqalat al-Islamiyyin (Publ.: Hellmut Bitter, 3rd Edition). Wiesbaden.

al-Ghazali, Abu Hamid Muhammad b. Muhammad. (1904). al-Mustasfa fi İlm al-Usul (Volume I-II). Cairo.

Goldziher, Ignaz. (1955). Mazahib al-Tafsir al-Islami (Arabic Translation: Abdulhalim an-Najjar). Cairo.

Ibn Hazm, Abu Muhammad Ali b. Ahmad az-Zahiri. (1975). al-Fasl fi'l-Milal wa'l-Ahwal wa'n-Nihal (Volume I-V). Beirut.

al-Qadi, Abu'l-Hasan Abduljabbar b. Ahmad al-Hamadani. (1965). Sharh al-Usul al-Hamsa (Edit: Abdulkerim Osman). Cairo.

(1969). Mutashabih al-Qur'an (Volume I-II, Edit: Adnan Muhammad Zarzur). Beirut: Dar al-Turath.

(1974). Fazl al-I’tizal wa Tabaqat al-Mu'tazila (Edit: Fuay Seyyid). Tunus. (no date). Tanzih al-Qur'an ani'l-Mata'in, Beirut: Dar alNahzat al-Hadisa.

al-Maturidi, Abu Mansur Muhammad b. Muhammad b. Mahmud al-Samarkandi. (1979). Kitab al-Tawhid (Edit: Fethullah Huleyf). İstanbul.

al-Razi, Fakhr al-Din Abu Abdillah Muhammad b. Omar. (no date), Mafatih al-Ghayb (Tafsir al-Kabir) (Volume I-XXXII). Beirut: Dar alIhya al-Turath al-Arabi.

al-Shahrastani, Abu'l-Fath Muhammad b. Abdilkarim. (1964). Nihayat al-Iqdam fi Ilm al-Kalam (Edit: Alfred Guilaume). London.

(1975). al-Milal wa'n-Nihal (Volume I-II, Edit: Muhammad Sayyid Kaylani). Beirut: Dar al-Ma'rifa.

al-Tahanawi, Muhammad b. Ali. (1984). Kashshaf al-Istilahat al-Funun (Volume I-II). İstanbul.

al-Zamakhshari, Abu'l-Qasim Jarullah Mahmud b. Omar. (no date). al-Kashshaf an Haqa'ik al-Tanzil wa Uyun al-Aqawil fi Wujuh alTa'wil (Volume I-IV). Beirut: Dar al-Ma'rifa. 